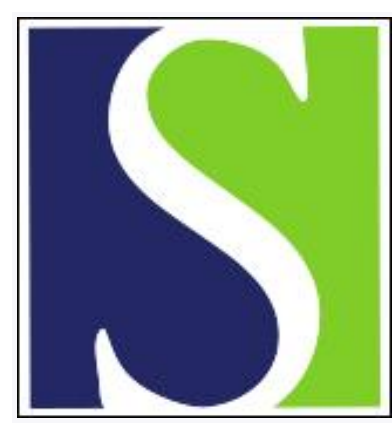

Scand J Work Environ Health 1990;16(6):428-433

https://doi.org/10.5271/sjweh.1764

Issue date: 01 Dec 1990

Relationship of airborne microorganisms with the lung function and leucocyte levels of workers with a history of humidifier fever.

by Kateman E, Heederik D, Pal TM, Smeets M, Smid T, Spitteler M

Affiliation: Department of Environmental and Tropical Health, University Wageningen, The Netherlands.

This article in PubMed: www.ncbi.nlm.nih.gov/pubmed/2284591

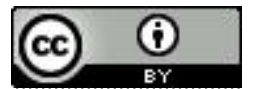




\title{
Relationship of airborne microorganisms with the lung function and leucocyte levels of workers with a history of humidifier fever
}

\author{
by Erik Kateman, MSc, ${ }^{1,2}$ Dick Heederik, PhD, ${ }^{1}$ Teake M Pal, MD, ${ }^{3}$ Marc Smeets, MSc,,${ }^{1,2}$ \\ Tjabe Smid, MSc, ${ }^{1,2}$ Martin Spitteler, MSc ${ }^{1,2}$
}

\begin{abstract}
KATEMAN E, HEEDERIK D, PAL TM, SMEETS M, SMID T, SPITTELER M. Relationship of airborne microorganisms with the lung function and leucocyte levels of workers with a history of humidifier fever. Scand J Work Environ Health 1990;16:428-33. An influenza-like illness appeared recently among workers in a plant processing synthetic yarn. A humidifier, a cold-water spraying system, was the suspected cause. Lung function changes over the day and week and changes in blood leucocytes were studied among the workers from the suspected department and two reference populations. Exposure to colonyforming units of bacteria and fungi and to endotoxins was also monitored. The workers from the suspected department had statistically significantly lower lung functions on the first workday of the week than the referents. Their blood leucocytes were also raised statistically significantly. The exposure to fungi, bacteria, and endotoxins differed significantly between the various departments, but the measured levels were low. It was concluded that the observed effects were suggestive of a "Monday morning fever" type of reaction and that adverse effects occurred at exposure levels lower than those found to date in the literature.
\end{abstract}

Key terms: endotoxins, humidifier fever, leucocytes, lung function.

In the autumn of 1985 the first two cases of an influenza-like illness were reported in a plant processing synthetic textile yarn. In both cases the symptoms were chest tightness and dyspnea, followed after a few hours by fever, malaise, and leucocytosis. The symptoms were the worst early in the week and disappeared by the end of the week. Later, similar cases occurred and were reported to the occupational physician.

In previous studies similar symptoms have been described in relation with endotoxin fever, humidifier fever, or Monday morning fever and extrinsic allergic alveolitis $(1-13)$. As etiologic agent(s) fungi, bacteria, amoeba, endotoxins, and antigenic material from humidifiers have been suggested.

The workers in the textile yarn processing plant only developed symptoms when working in an area where the air was humidified with a cold-water spray humidifier. Therefore, the relationship between lung function changes (during the work week) and a change in the level of peripheral leucocytes (during the first day), and exposure differences in workers in three areas with different humidifier systems were studied. We focused in this study on differences in exposure to fungi, bacteria, and endotoxins between the workers in the suspected (exposed) area and two other populations of workers in similar work areas.

1 University Wageningen, Department of Environmental and Tropical Health, Wageningen, The Netherlands.

2 University Wageningen, Department of Air Pollution, Wageningen, The Netherlands.

${ }^{3}$ AKZO Medical Department, Emmen, The Netherlands.

Reprint requests to: Dr D Heederik, University Wageningen, Department of Environmental and Tropical Health, PO Box 238, 6700 AE Wageningen, The Netherlands.

\section{Subjects and methods}

The exposed group consisted of 40 male workers, of whom $25 \%$ were nonsmokers and $18 \%$ were exsmokers. This group was involved in the winding of synthetic (polyester and polyamide) textile yarn. The first reference group consisted of 19 male workers ( $26 \%$ nonsmokers, $11 \%$ ex-smokers). The men in this reference group worked in the same department on similar winding machines but in an area where the air was humidified by a steam humidification system instead of a cold-water humidification system. A second reference group consisted of 23 men who worked in another department on similar machines without a humidification system (26\% nonsmokers, $4 \%$ exsmokers). The mean age of all three groups was 30 years. The mean standing height of the workers was $180 \mathrm{~cm}$, and the means did not differ statistically significantly between the three groups.

At fixed points in the three areas, $1.5 \mathrm{~m}$ above the floor, total and inhalable dust was measured with a sampling time of $8 \mathrm{~h}$. Total dust was measured with modified Schleicher \& Schüll PL050/1 filter holders. The suction flow was calibrated at a face velocity of $1.25 \mathrm{~m} / \mathrm{s}(14)$. Inhalable dust ( $50 \%$ cut-off diameter $<8.5 \mu \mathrm{m}$ ) was measured with a cyclone preseparator (15).

Personal inspirable dust samples were taken with socalled PAS-6 filter holders at a flow rate of $2 \mathrm{l} / \mathrm{min}$ (16). All the exposure measurements were made with Whatman GF/A glass fiber filters. The average sampling time was $6 \mathrm{~h}$ for all the dust exposure measurements.

Viable fungal spores, total numbers of bacteria, and gram negative bacteria were measured as colony- 
forming units (cfu) per cubic meter with the N6 modification of the Andersen sampler (17) according to a previously described method (18). The measurements were performed at $1.5 \mathrm{~m}$ above the floor in the same locations used for the dust sampling. The sampling time was $8 \mathrm{~min}$. In all cases duplicate samples were taken, and the measurements were repeated twice a day. The samplers were loaded with petri dishes containing malt extract agar with oxytetracycline (MEA) for fungi, peptone in a sodium chloride solution (PCA) for the total number of bacteria, and peptone in a sodium chloride solution with crystalviolet $\left(\mathrm{PCA}^{+}\right)$for gram negative bacteria. The exact constitution of the media can be found in the literature (18). The MEA dishes were incubated at $24^{\circ} \mathrm{C}$ for $5 \mathrm{~d}$ and counted by visual inspection. The PCA and $\mathrm{PCA}^{+}$dishes were incubated at $30^{\circ} \mathrm{C}$ for $5 \mathrm{~d}$ and counted by visual inspection after $5 \mathrm{~d}$.

Endotoxins were determined per work area in pooled personal dust samples. For this purpose samples were pooled per day and a random test sample of five pooled dust samples was taken for each work area. The analyses were done in our laboratory according to a previously described procedure (19), using the Coatest Endotoxin Test Kit (Kabivitrum, Sweden). The filter extract was split into two fractions and spiked with a known quantity of endotoxin delivered with the test kit. The recovery appeared to be approximately $100 \%$ (range $89-112 \%, \mathrm{~N}=15$ ).

The prevalence of respiratory symptoms was recorded with a short respiratory questionnaire commonly used in The Netherlands (20). It consisted of items of the internationally accepted questionnaire of the British Medical Research Council.

Spirometric measurements were performed with a Vicatest-5 dry rolling seal spirometer (Mijnhardt, The Netherlands) with automatic data processing. Calibration was performed with a Pull-mark 3-1 calibration syringe. On each occasion at least three acceptable tests were made. For each parameter the highest value of the three best (corrected for body temperature and pressure saturated with water vapor) test curves was used in the analyses. This procedure is in agreement with the recommendations of the European Committee on Coal and Steel (21).

The following pulmonary function variables were obtained: forced vital capacity (FVC), forced expiratory volume in $1 \mathrm{~s}\left(\mathrm{FEV}_{1.0}\right)$, FEV \% [(100 $\left.\mathrm{FEV}_{1.0}\right) /$ FVC], peak expiratory flow (PEF), maximum expiratory flow at $25 \%$ of the FVC $\left(\mathrm{MEF}_{75}\right)$, maximum expiratory flow at $50 \%$ of the FVC $\left(\mathrm{MEF}_{50}\right)$, maximum expiratory flow at $75 \%$ of the FVC $\left(\mathrm{MEF}_{25}\right)$, maximum midexpiratory flow (MMEF). The mean coefficient of variation $\left(\mathrm{CV}_{t}\right)$ for the three blows was $1 \%$ for the FVC, $2.0 \%$ for the $\mathrm{FEV}_{1.0}, 8.2 \%$ for the PEF, 8.1 \% for the $\mathrm{MEF}_{75}, 8.3 \%$ for the $\mathrm{MEF}_{50}$, $11.3 \%$ for the $\mathrm{MEF}_{25}$, and $6.1 \%$ for the MMEF.

Blood samples for the counting of white blood cells were collected in vacuum tubes with anticlotting fac- tor (Venoject). The white blood cells were counted with an ELT-8 Coulter counter (Ortho Diagnostic System Inc). Between the collection and analysis, the samples were stored for a maximum of $24 \mathrm{~h}$ in a refrigerator at $6^{\circ} \mathrm{C}$.

The dust and endotoxin measurements were taken during the afternoon shift $(1400-2200)$ on the first, second, and fifth workday after a work-free period of $3 \mathrm{~d}$. The microbiological measurements were taken on the second workday. The spirometric tests were performed on the same days as the dust measurements shortly after the beginning and shortly before the end of the shift. The blood samples for the counting of the white blood cells were taken after the lung function tests at the beginning and end of the first workday and at the beginning of the second and fifth workdays. All the measurements were performed during a 5-week period.

Using multiple regression analysis, we studied the differences in lung function between the groups working in the area with and without a humidification system. For these cross-sectional analyses the groups with cold-water and steam humidification were combined because of regular shifting between the two types of work areas. The lung function parameters were included as dependent variables. The work area and confounding variables like smoking, age, and standing height were entered in all the models as independent variables in the equations. In all the calculations smoking was expressed as pack-years. This is the product of the number of years a person has smoked and the packs of cigarettes smoked per day. Cigar consumption was recalculated to pack-years. It was assumed that one cigar equaled to two cigarettes.

Changes in lung function over the day or workweek were studied for all three groups separately (cold-water humidification, steam humidification, no humidification). This evaluation was possible because job shifting between the cold-water humidification and steam humidification occurred on a weekly basis only. Differences in the group means of the lung function changes were analyzed with Student's t-test.

All the data were analyzed with SAS (statistical analysis system) software. After inspection of the distributions and tabular analysis a regression analysis was performed with the lung function data.

\section{Results}

\section{Dust measurements}

The dust exposure was low and ranged from 0.1 to $0.3 \mathrm{mg} / \mathrm{m}^{2}$. The group means of the personal exposure to inhalable dust of $0.6 \mathrm{mg} / \mathrm{m}^{3}$ (exposed group) and $0.5 \mathrm{mg} / \mathrm{m}^{3}$ (for both reference groups) did not differ significantly $(\mathrm{P}>0.10$ on log-transformed concentrations, t-test). No significant differences between the three groups were found for the environmental ex- 
posure to total dust or inhalable dust. Considering the fact that most of the values were below the detection limit in all three exposure groups, the absence of significant differences was not surprising.

\section{Endotoxin measurements}

The distribution of endotoxin measurements appeared, by visual inspection, to be log-normal. The geometric mean was 64 (GSD 1.6) pg/m $/ \mathrm{m}^{3}$ for the cold-water humidification area, $18 \mathrm{pg} / \mathrm{m}^{3}$ for the departments with a steam humidification system, and $19 \mathrm{pg} / \mathrm{m}^{3}$ for those without a humidification system. It was found that the level of endotoxins was significantly $(P<0.05$, t-test) higher in the area with the cold-water spray humidification than in that with the steam humidification or that without humidification.

\section{Microbiological measurements}

The mean number of colony-forming units was calculated on the basis of the duplicate samples. The distribution of the number of colony-forming units of fungi and the total number of colony-forming units of bacteria and of gram-negative bacteria were skewed to the right and resembled a log-normal distribution. Therefore the geometric means and the geometric standard deviations were calculated; they are given in table 1 . It was found that the mean of the log of the number of colony-forming units for fungi was significantly elevated $(P<0.05$, $t$-test $)$ in the area with steam humidification when it was compared to the area with a cold-water humidification system and the area without humidification. In contrast, the number of colonyforming units for total bacteria and gram-negative bacteria was significantly $(P<0.01, t$-test $)$ higher in the area with cold-water spray humidification than in the area with steam humidification or no humidification.
Although no detailed determination of the species present was made, incubation of a few samples at temperatures above $30^{\circ} \mathrm{C}$ revealed no thermophilic actinomyces species.

\section{Symptoms and spirometry}

Since the workers in the areas with steam humidification and those in the areas with cold-water humidification alternately worked in both areas, they were treated as one group (humidification) for this analysis. The prevalence of respiratory symptoms like cough, sputum, and shortness of breath was low $(<5 \%)$ for all the subpopulations. A high percentage of workers $(25 \%)$ complained of wheezing, but there was no difference between the subpopulations.

A cross-sectional analysis of the pulmonary function data was performed using the pulmonary function scores at the start of the first workday. The analysis showed that, except for the PEF, no significant differences between the group means of the lung function scores existed after allowance was made for smoking, age, and standing height.

A short longitudinal analysis was performed using the change in the lung function scores from the start to the end of the shift on the first, second, and fifth workday after a work-free period of $3 \mathrm{~d}$. For this analysis the population was broken down into three groups. The characteristics of the three groups are given in table 2 . The group means of the lung function changes during the first, second, and fifth workdays are given in table 3 for each group. A linear regression analysis in which we allowed for smoking showed similar results. For some lung function variables a decrease over the week was visible for the workers from the area with the cold-water humidification; corresponding decreases were not found for the other workers. The $\mathrm{MEF}_{75}$ gave the most revealing pattern (figure 1). The work-

Table 1. Exposure levels of fungi, bacteria, and gram-negative bacteria. (cfu =colony-forming units)

\begin{tabular}{|c|c|c|c|c|c|c|c|c|c|}
\hline \multirow[b]{2}{*}{$\begin{array}{l}\text { Humidification } \\
\text { system }\end{array}$} & \multicolumn{3}{|c|}{ Fungi } & \multicolumn{3}{|c|}{ Bacteria } & \multicolumn{3}{|c|}{ Gram-negative bacteria } \\
\hline & Number & $\begin{array}{c}\text { Geometric } \\
\text { mean } \\
\left(\mathrm{cfu} / \mathrm{m}^{3}\right)\end{array}$ & $\begin{array}{l}\text { Geometric } \\
\text { standard } \\
\text { deviation }\end{array}$ & Number & $\begin{array}{c}\text { Geometric } \\
\text { mean } \\
\left(\mathrm{cfu} / \mathrm{m}^{3}\right)\end{array}$ & $\begin{array}{l}\text { Geometric } \\
\text { standard } \\
\text { deviation }\end{array}$ & Number & $\begin{array}{c}\text { Geometric } \\
\text { mean } \\
\left(\mathrm{cfu} / \mathrm{m}^{3}\right)\end{array}$ & $\begin{array}{l}\text { Geometric } \\
\text { standard } \\
\text { deviation }\end{array}$ \\
\hline Cold-water & 6 & 7.5 & 1.7 & 6 & 292.0 & 1.8 & 6 & 42.1 & 1.6 \\
\hline Steam & 6 & $16.2^{\star \star}$ & 1.5 & 6 & $47.0^{* \star \star}$ & 1.4 & 6 & $6.5^{* * *}$ & 1.6 \\
\hline None & 6 & $4.2^{\star * *}$ & 1.8 & 6 & $37.8^{* * *}$ & 1.5 & 5 & $9.8^{* * *}$ & 2.2 \\
\hline
\end{tabular}

** $P<0.05$, (two-sided t-test against cold-water humidification group), $* * 1 P<0.01$ (two-sided t-test against steam humidification group), $* * * P<0.01$ (two-sided t-test against cold-water humidification group).

Table 2. Mean age, height, and smoking habits of the population which participated in the workshift lung function study.

\begin{tabular}{|c|c|c|c|c|c|c|c|c|}
\hline \multirow{2}{*}{$\begin{array}{l}\text { Humidification } \\
\text { system }\end{array}$} & \multirow{2}{*}{ Number } & \multicolumn{2}{|c|}{ Age (years) } & \multicolumn{2}{|c|}{ Height (cm) } & \multirow{2}{*}{$\begin{array}{l}\text { Smokers } \\
\qquad(\%)\end{array}$} & \multirow{2}{*}{$\begin{array}{c}\text { Ex-smokers } \\
(\%)\end{array}$} & \multirow{2}{*}{$\begin{array}{c}\text { Nonsmokers } \\
(\%)\end{array}$} \\
\hline & & Mean & SD & Mean & $\mathrm{SD}$ & & & \\
\hline $\begin{array}{l}\text { Cold-water } \\
\text { Steam } \\
\text { None }\end{array}$ & $\begin{array}{l}32 \\
12 \\
16\end{array}$ & $\begin{array}{l}31 \\
31 \\
34\end{array}$ & $\begin{array}{r}9 \\
8 \\
11\end{array}$ & $\begin{array}{l}179 \\
181 \\
178\end{array}$ & $\begin{array}{l}7 \\
8 \\
6\end{array}$ & $\begin{array}{l}56 \\
67 \\
69\end{array}$ & $\begin{array}{r}22 \\
8 \\
6\end{array}$ & $\begin{array}{l}22 \\
25 \\
25\end{array}$ \\
\hline
\end{tabular}




\section{Change in MEF75}

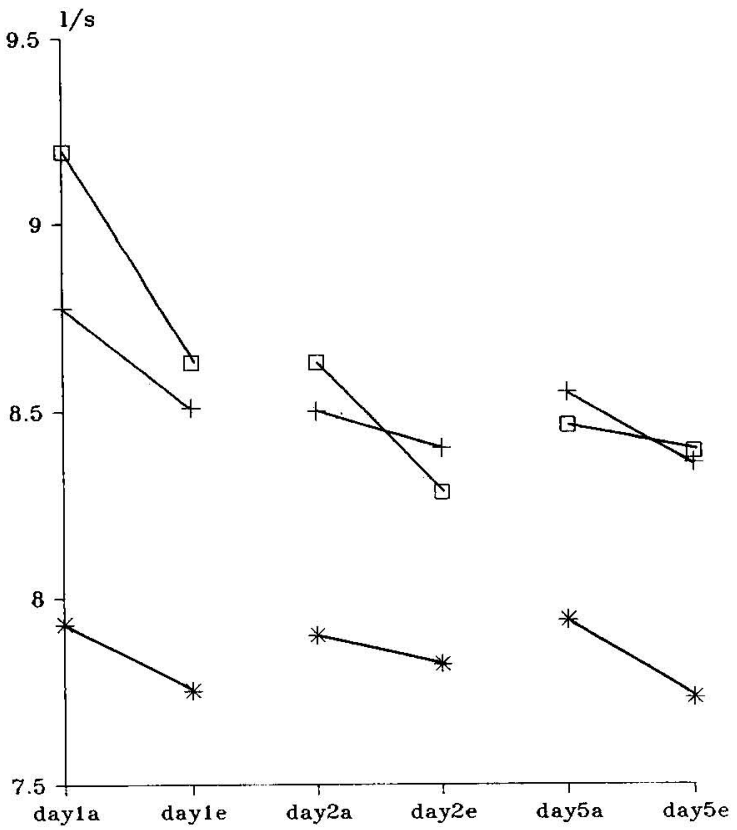

Figure 1. Change in maximum expiratory flow at $25 \%$ of the forced vital capacity $\left(\mathrm{MEF}_{75}\right)$ over the day and week for the three populations. (day1a = shortly after beginning of first workday of week, day $1 \mathrm{e}=$ shortly after end of first workday of week, day $2 \mathrm{a}=$ shortly after beginning of second workday of week, day $2 e=$ shortly after end of second workday of week, day $5 a=$ shortly after beginning of fifth workday of week, day $5 \mathrm{e}=$ shortly after end of fifth workday of week)

ers in the cold-water humidification area showed a decrease in $\mathrm{MEF}_{75}$ which was strongest during the first workday $(6 \%)$ and less the second workday (4\%), while there was no apparent change during the fifth workday even though the lung function level on Friday was reduced when compared with the initial Monday values. A similar pattern was found for the MMEF and the FEV \%. The decrease in the $\mathrm{MEF}_{75}$, MMEF, FEV \%, and $\mathrm{FEV}_{1.0}$ during the first workday was consistent during the rest of the workweek.

\section{Blood}

According to information on the intraperson variation of leucocytes in peripheral blood, a person was considered to have an elevated increase in the leucocyte level on the first workday if the change in the number of leucocytes in the blood over the day was more than the average change plus three times the standard deviation of the reference population without a humidification system. The criterion used is in close agreement with reference values published by Costongs et al (22). With this criterion the population was dichotomized
Table 3. Change in lung function for the three groups with cold-water, steam, or no humidification system. (FVC $=$ forced vital capacity, $\mathrm{FEV}_{1.0}=$ forced expiratory volume in $1 \mathbf{s}$ $\mathrm{MMEF}=$ maximum midexpiratory flow, $\mathrm{FEV} \%=\left[\left(100 \times \mathrm{FEV}_{1.0}\right) /\right.$ FVC], $P E F=$ peak expiratory flow, $M F_{25}=$ maximum expiratory flow at $25 \%$ of the FVC, MEF $F_{50}=$ maximum expiratory flow at $50 \%$ of the $F V C, M E F_{25}=$ maximum expiratory flow at $75 \%$ of the FVC.)

\begin{tabular}{|c|c|c|c|c|c|c|}
\hline & \multicolumn{6}{|c|}{ Humidification system } \\
\hline & \multicolumn{2}{|c|}{$\begin{array}{l}\text { Cold-water } \\
(\mathrm{N}=32)\end{array}$} & \multicolumn{2}{|c|}{$\begin{array}{c}\text { Steam } \\
(\mathrm{N}=12)\end{array}$} & \multicolumn{2}{|c|}{$\begin{array}{c}\text { None } \\
(N=16)\end{array}$} \\
\hline & Mean & SD & Mean & SD & Mean & $\overline{S D}$ \\
\hline \multicolumn{7}{|l|}{ FVC (1) } \\
\hline $\begin{array}{l}\text { Day } 1 \\
\text { Day } 2 \\
\text { Day } 5\end{array}$ & $\begin{array}{l}=0.022 \\
-0.042^{\star} \\
-0.057^{*}\end{array}$ & $\begin{array}{l}0.143 \\
0.137 \\
0.145\end{array}$ & $\begin{array}{r}-0.044 \\
0.053 \\
-0.034\end{array}$ & $\begin{array}{l}0.127 \\
0.115 \\
0.100\end{array}$ & $\begin{array}{r}-0.046 \\
0.068 \\
-0.003\end{array}$ & $\begin{array}{l}0.148 \\
0.172 \\
0.099\end{array}$ \\
\hline \multicolumn{7}{|l|}{ FEV $_{1.0}(I)$} \\
\hline $\begin{array}{l}\text { Day } 1 \\
\text { Day } 2 \\
\text { Day } 5\end{array}$ & $\begin{array}{l}-0.096^{\star *} \\
-0.065^{\star *} \\
-0.067^{\star *}\end{array}$ & $\begin{array}{l}0.159 \\
0.134 \\
0.130\end{array}$ & $\begin{array}{l}-0.054 \\
-0.004 \\
-0.049\end{array}$ & $\begin{array}{l}0.190 \\
0.125 \\
0.160\end{array}$ & $\begin{array}{c}-0.082^{*} \\
0.014 \\
-0.040\end{array}$ & $\begin{array}{l}0.133 \\
0.133 \\
0.110\end{array}$ \\
\hline \multicolumn{7}{|c|}{ MMEF (I/s) } \\
\hline $\begin{array}{l}\text { Day } 1 \\
\text { Day } 2 \\
\text { Day } 5\end{array}$ & $\begin{array}{l}-0.265^{\star *} \\
-0.106^{*} \\
-0.093^{*}\end{array}$ & $\begin{array}{l}0.320 \\
0.321 \\
0.284\end{array}$ & $\begin{array}{l}-0.101 \\
-0.084 \\
-0.084\end{array}$ & $\begin{array}{l}0.599 \\
0.211 \\
0.443\end{array}$ & $\begin{array}{l}-0.121^{\star} \\
-0.038 \\
-0.152^{\star}\end{array}$ & $\begin{array}{l}0.193 \\
0.175 \\
0.298\end{array}$ \\
\hline \multicolumn{7}{|l|}{ FEV $\%$} \\
\hline $\begin{array}{l}\text { Day } 1 \\
\text { Day } 2 \\
\text { Day } 5\end{array}$ & $\begin{array}{l}-1.357 \\
-0.654^{*} \\
-0.398\end{array}$ & $\begin{array}{l}1.982 \\
1.711 \\
1.820\end{array}$ & $\begin{array}{l}-0.240 \\
-0.772^{*} \\
-0.378\end{array}$ & $\begin{array}{l}3.461 \\
1.357 \\
1.966\end{array}$ & $\begin{array}{l}-0.924^{\circ} \\
-0.704 \\
-0.629\end{array}$ & $\begin{array}{l}1.460 \\
1.693 \\
1.513\end{array}$ \\
\hline \multicolumn{7}{|l|}{ PEF (1/s) } \\
\hline $\begin{array}{l}\text { Day } 1 \\
\text { Day } 2 \\
\text { Day } 5\end{array}$ & $\begin{array}{r}-0.186 \\
0.030 \\
-0.224\end{array}$ & $\begin{array}{l}0.881 \\
0.860 \\
1.267\end{array}$ & $\begin{array}{r}0.463 \\
0.361 \\
-0.048\end{array}$ & $\begin{array}{l}1.065 \\
1.140 \\
0.466\end{array}$ & $\begin{array}{r}0.264 \\
0.702 \\
-0.092\end{array}$ & $\begin{array}{l}0.882 \\
0.945 \\
0.686\end{array}$ \\
\hline \multicolumn{7}{|c|}{$\mathrm{MEF}_{75}(\mathrm{l} / \mathrm{s})$} \\
\hline $\begin{array}{l}\text { Day } 1 \\
\text { Day } 2 \\
\text { Day } 5\end{array}$ & $\begin{array}{l}-0.560^{* *} \\
-0.342^{* *} \\
-0.072\end{array}$ & $\begin{array}{l}0.895 \\
0.567 \\
0.622\end{array}$ & $\begin{array}{l}-0.277^{*} \\
-0.103 \\
-0.193\end{array}$ & $\begin{array}{l}1.052 \\
0.503 \\
0.620\end{array}$ & $\begin{array}{l}-0.183^{*} \\
-0.080 \\
-0.211^{\star}\end{array}$ & $\begin{array}{l}0.382 \\
0.663 \\
0.452\end{array}$ \\
\hline \multicolumn{7}{|c|}{$\mathrm{MEF}_{50}(/ / \mathrm{s})$} \\
\hline $\begin{array}{l}\text { Day } 1 \\
\text { Day } 2 \\
\text { Day } 5\end{array}$ & $\begin{array}{l}-0.242^{* *} \\
-0.046 \\
-0.076\end{array}$ & $\begin{array}{l}0.531 \\
0.591 \\
0.452\end{array}$ & $\begin{array}{c}0.024 \\
-0.222^{*} \\
-0.212\end{array}$ & $\begin{array}{l}0.815 \\
0.316 \\
0.593\end{array}$ & $\begin{array}{l}-0.215^{* *} \\
-0.135 \\
-0.082\end{array}$ & $\begin{array}{l}0.312 \\
0.352 \\
0.396\end{array}$ \\
\hline \multicolumn{7}{|c|}{$\mathrm{MEF}_{25}(\mathrm{l} / \mathrm{s})$} \\
\hline $\begin{array}{l}\text { Day } 1 \\
\text { Day } 2 \\
\text { Day } 5\end{array}$ & $\begin{array}{l}-0.150^{* *} \\
-0.067 \\
-0.064^{*}\end{array}$ & $\begin{array}{l}0.314 \\
0.234 \\
0.214\end{array}$ & $\begin{array}{r}-0.160 \\
-0.110 \\
0.029\end{array}$ & $\begin{array}{l}0.414 \\
0.238 \\
0.371\end{array}$ & $\begin{array}{l}-0.095 \\
-0.032 \\
-0.085\end{array}$ & $\begin{array}{l}0.303 \\
0.220 \\
0.215\end{array}$ \\
\hline
\end{tabular}

* $P<0.05$ (paired $t$-test, one-sided), ** $P<0.01$ (paired t-test, one sided).

Table 4. Normal, high, and total change in the leucocyte level in the blood of the three humidifier groups over the first workday.

\begin{tabular}{lrcc}
\hline Humidification system & High $^{\mathrm{a}}$ & Normal $^{\mathrm{b}}$ & Total \\
\hline Cold-water & 14 & 16 & 30 \\
Steam & 5 & 8 & 13 \\
None & 2 & 16 & 18 \\
\hline Total & 21 & 40 & 61 \\
\hline
\end{tabular}

a $\geq 20 \times 10^{8}$ cells $\cdot 1^{-1}$

b $20 \times 10^{8}$ cells $\cdot 1^{-1}$.

into groups with a normal and elevated change of leucocytes during the first day. The results are given in table 4 . The group working in the area with cold-water humidification had a significantly $(\mathrm{P}<0.05$, Fisher exact test) higher proportion of people with an elevated leucocyte count than the group working in the area without a humidification system. 


\section{Discussion}

In this study we compared workers in an area with a cold-water humidification system and a history of disease with workers in other areas. The reference areas were similar industrial environments, but had different humidification systems. One of the reference areas had a steam humidification system. In the other one no humidification system was present. The workers in the reference areas had no apparent history of disease which might be related to a humidification system.

The concentrations of total bacteria, gram-negative bacteria, and endotoxins in the area with spray humidification were higher than in the area with steam humidification and in the area without humidification. For fungi we found a reversed, and statistically significant, relationship. The number of colony-forming units for fungi was higher in the area with steam humidification than in the other two reference areas. No thermophilic actinomyces species were present. Although we found statistically significant differences between the three departments in the endotoxin level and the numbers of colony-forming units, the exposure levels were lower than in other industrial situations or even lower than outdoor levels previously reported by our laboratory (18). A comparison with another study in which measurements in 21 work environments with different kinds of humidification systems were described also showed that the exposures which were found in this study were relatively low when compared with other experiences, while the measurement techniques used and procedures followed were comparable (23).

Concentrations were also low in comparison with levels reported in effect studies. For instance the effects of endotoxin on lung function have been described at higher concentrations than encountered in this study. Experimental inhalation studies with cotton dust containing endotoxin provoked an acute effect on pulmonary function at an endotoxin level that was at least 1000 times higher than that measured in our study (24). However, in another study, acute respiratory effects among persons with respiratory complaints appeared at levels which were approximately 100 times higher (25). Inhalation experiments with purified endotoxins of various gram-negative bacteria have provoked respiratory changes and also fever (26-28). The lowest injected dose which provoked fever $(0.1-0.5 \mathrm{ng} / \mathrm{kg}$ Escherichi coli endotoxin) can be recalculated to an endotoxin concentration in the air if one assumes a breathing volume of $15 \mathrm{~m}^{3} / \mathrm{d}$ for a 70-kg man, a $50 \%$ deposition, and $100 \%$ resorption of respirable endotoxin in the lung, as earlier proposed by Rylander \& Morey (29). This procedure leads to endotoxin levels in the air ranging from 1 to $5 \mathrm{ng} / \mathrm{m}^{3}$, only a factor of 10 higher than the levels found in this study. Therefore, the exposure levels measured in this study were lower than those reported in an experimental effect study and were also lower than those suggested as a threshold limit value for endotoxins (30).

It is recognized that differences in analytical procedures can result in dramatic differences in the outcome of exposure studies. For the measurement of both viable fungi and endotoxins this problem has been discussed in the literature recently $(17,18,30,31)$. However the measurements of viable fungi and endotoxins performed by our laboratory in other occupational settings, such as swine confinement buildings and grain elevators, are clearly in concordance with the results of other published studies and are not suggestive of a serious underestimation of exposure levels $(18,19$, 32,33 ). The use of glass fiber filters instead of absolute filters might be a factor which could have contributed to an underestimation of the endotoxin exposure in this specific low-exposure situation. However, no quantitative information exists on the performance of different filter types, and this suggestion remains speculative. Interference in the analysis by contaminating substances seems unlikely because the procedure of spiking the filter extracts with reference endotoxin did not point to any interference. It is however recognized that the sampling and analytical procedures commonly in use deserve more attention in the near future (31).

Nevertheless, the workers in the suspected area showed a marked decrease in lung function over the first workday and over the week in comparison with the workers from the two other areas. These changes in lung function correlated with the differences in exposure to airborne agents between these work areas. The reduction in lung function over the week points to an obstructive reaction during the first workday, which is less profound during the week. The lower lung function level reached during the first day remained during the rest of the week. The respiratory symptoms, and the pattern of this lung function change are not suggestive of an asthmatic reaction because the changes in lung function were small. No subgroup with extreme decreases in lung function could be identified. All the workers seemed to be involved because the standard deviations of the mean changes in lung function for the consecutive shifts remained constant. The magnitude of the decreases in lung function were in the same range as those published in another study (1). This marked decrease in pulmonary function on the first day, together with an increase in the level of leucocytes in blood on the first day, points to a "Monday morning fever" type of reaction. An inflammatory response might be the underlying mechanism, although other mechanisms cannot be excluded. Before this hypothesis can be validated, additional information is necessary.

Our findings suggest that microorganisms or endotoxins or other unmeasured exposures which are quantitatively related to the endotoxin and colonyforming unit levels are the responsible agents. A further characterization of the species present and an anal- 
ysis of the relationships between the number of colonyforming units and the (endo)toxin levels present is necessary to confirm this impression. Despite the fact that we did not make a qualitative assessment of the species involved, our findings suggest that health effects can be expected at lower exposure levels in terms of colony-forming units and endotoxin levels, although we cannot exclude differences in analytical procedures completely.

\section{References}

1. Ashton I, Axford AT, Bevan C, Cotes JE. Lung function of office workers exposed to humidifier fever antigen. Br J Ind Med 1981;38:34-7.

2. Banaszak EF, Thiede W, Fink J. Hypersensitivity pneumonitis due to a contaminated air conditioner. N Engl J Med 1970;283:171

3. Burge S, Finnigan M, Horsefield N, et al. Occupational asthma in a factory with a contaminated humidifier. Thorax 1985;40:248-54.

4. Cockcroft A, Edwards J, Bevan C, et al. An investigation of operating theatre staff exposed to humidifier fever antigens. Br J Ind Med 1981;38:144-51.

5. Edwards JH. Microbial and immunological investigations and remedial action after an outbreak of humidifier fever. Br J Ind Med 1980;37:55-62.

6. Edwards JH. Organic dust disease and endotoxins. Rev Epidemiol Sante Publique 1981;29:199-207.

7. Flaherty DK, Deck FH, Cooper J, et al. Bacterial endotoxin isolated from a water spray air humidification system as a putative agent of occupation-related disease. Infect Immun 1984;43(1):206-12.

8. Flaherty DK, Deck FH, Hood MA, et al. A cytophaga species endotoxin as a putative agent of occupation related lung disease. Infect Immun 1984;43(1):213-6.

9. Pickering CAC, Moore WKS, Lacey J, Holford-Stevens $\mathrm{VC}$, Pepys $\mathbf{J}$. Investigation of a respiratory disease associated with an air-conditioning system. Clin Allergy 1976;6:109-18.

10. Reed CE, Swanson MC, Lopez M, et al. Measurement of IgG antibody and airborne antigen to control an industrial outbreak of hypersensitivity pneumonitis. J Occup Med 1983;25:207-10.

11. Rylander R, Haglind P, Lundholm M, Mattsby I, Stenqvist K. Humidifier fever and endotoxin exposure. Clin Allergy 1978;8:511-6.

12. Roberton AS, Burge PS, Wieland GA, Carmalt MHB. Extrinsic allergic alveolitis caused by a cold water humidifier. Thorax 1987;42:32-7.

13. Anderson K, Watt AD, Sinclair D, Lewis C, McSharry $\mathrm{CP}$, Boyd $\mathrm{G}$. Climate, intermittent humidification, and humidifier fever. $\mathrm{Br} J$ Ind Med 1989;46:671-4.

14. Staubforschungsinstitut des Hauptverbandes der gewerblichen Berufsgenossenschaft ev (Bonn), Silikose Forschungsinstitut der Bergbauberufsgenossenschaft (Bochum). Empfelungen zur Messung und Beurteilungen von gesundheitsgefährlichen Staüben. StaubReinhalt Luft 1973;33:1-3.

15. Vrins E, Hofschreuder P. Sampling total suspended particulate matter. J Aerosol Sci 1983;14:318-21.

16. ter Kuile WM. Vergleichsmessungen mit verschiedenen Geräten zur Bestimmung der Gesamtstaubkonzentration am Arbeitsplatz. Teil II. Staub-Reinhalt Luft 1984;44: $211-6$.

17. Jones W, Morring K, Morey P, Sorenson W. Evalua- tion of the Andersen viable impactor for single stage sampling Am Ind Hyg Assoc J 1985;46:294-8.

18. Smid T, Schokkin E, Boleij J, Heederik D. Enumeration of viable fungi in occupational environments. Am Ind Hyg Assoc J 1989;50:235-9.

19. Attwood P, Brouwer R, Ruigewaard P, et al. A study of the relationship between airborne contaminants and environmental factors in Dutch swine confinement buildings. Am Ind Hyg Assoc J 1987;48:745-51.

20. Biersteker K, van Dijk WH, Eissens JBMF, van Geens HA. Ervaringen met geneeskundig onderzoek op CARA bij gemeentepersoneel te Rotterdam, 1970-1971 [The prevalence of CNSLD in male municipal employees in Rotterdam]. Tijdschr Soc Geneesk 1974; 32:158-62. (English abstract.)

21. Quanjer $\mathrm{PH}$, ed. Standardized lung function testing: report of the working party standardization of lung function tests of the European Community for Coal and Steel, Luxembourg. Bull Eur Physiopathol Respir 1983; 19(suppl): $1-95$.

22. Costongs GMPJ, Janson PCW, Bas BM. Short-term and long-term intra-individual variations and critical differences of hematological laboratory parameters. J Clin Chem Clin Biochem 1985;23:69-76.

23. Morey P. Suspended viable particles, allergens and other particulate matter. Presented at a WHO workshop on indoor quality, Rautavaara (Finland), 1988.

24. Rylander $R$, Haglind $P$. Relation between FEV changes over workshift and cotton/endooxin levels. In: Wakelyn PJ, Jacobs RR, ed. Proceedings of the seventh cotton dust research conference. Memphis, TN: National Cotton Council, 1983:17-8.

25. Castellan RM, Olenchock SA, Hankinson JL, Millner PD, Cock JB, Bragg CK. Acute bronchoconstriction induced by cotton dust: dose-related responses to endotoxin and other dust factors. Ann Int Med 1984;101: 157-63.

26. Elin RJ, Wolff SM, McAdam KP, et al. Properties of reference Escherichia coli endotoxin and its phthalylated derivatives in humans. J Infect Dis 1981;144:329-36.

27. van der Zwan JC, Orie NMG, Kaufmann HF, Wiers PWJ, de Vries K. Bronchial obstructive reactions after inhalation with endotoxin and precipitinogens of Haemophilus influenzae in patients with chronic non-specific lung disease. Clin Allergy 1982;12:547-59.

28. Rylander R, Bake B, Fischer FF, Helander IM. Pulmonary function and symptoms after inhalation of endotoxin. Am Rev Respir Dis 1989;140:981-6.

29. Rylander R, Morey P. Airborne endotoxin in industries processing vegetable fibers. Am Ind Hyg Assoc J 1983; 43:811-2

30. Palchak RB, Cohen R, Ainslie M, Hoorner CL. Airborne endotoxin associated with industrial scale production of protein products in gram-negative bacteria. Am Ind Hyg Assoc J. 1988;49:420-1.

31. Olenchock SA, Lewis DM, Mull JC. Effects of different extraction protocols on endotoxin analyses of airborne grain dusts. Scand J Work Environ Health 1989; 15:430-5.

32. Attwood P, Versloot P, Heederik D, de Wit R, Boleij JSM. Assessment of dust and endotoxin levels in the working environment of Dutch pig farmers: a preliminary study. Ann Occup Hyg 1986;30:201-8.

33. Heederik D, Smid $T$. The relationship between lung function, dust exposure and endotoxin exposure in animal feed workers. In: Sakurai H, Okazaki I, Omae K, ed. Occupational epidemiology. Amsterdam: Exerpta Medica, 1990:161-4.

Received for publication: 3 November 1989 